\title{
Changes in migration and wintering patterns of Greylag Geese Anser anser from southernmost Sweden during three decades
}

\author{
Förändringar i flyttnings- och övervintringsvanor hos grågäss Anser anser från \\ sydligaste Sverige under trettio år
}

LEIF NILSSON \& HAKON KAMPE-PERSSON

The recent increase of the Greylag Goose Anser anser
population has caused complaints about crop damage. In
response to this, the Nordic Collegium for Wildlife Re-
search started a neck-banding program to elucidate the
migration and movement patterns. During 1984-2009,
2639 Greylag Geese were marked in a breeding area in
SW Scania, southernmost Sweden. Up to and including
2012,15296 re-sightings were reported from outside the
breeding area (in addition to more than 100 000 from
the breeding area). In the early years of the study, the
majority of the geese migrated to winter in southernmost
Spain, staging in The Netherlands. In later years, hard-
ly any individuals migrated to Spain, the majority stay-
ing in The Netherlands with an increasing proportion

\section{Abstract}

wintering in southern Sweden. From 1986 to 2017, the mean latitude for re-sightings changed ten degrees to the north. About $13 \%$ of the geese changed winter quarters between two consecutive winters. Moreover, the southward migration occurred much later in the autumn and the geese returned to the breeding areas about one month earlier in spring.

Leif Nilsson, Department of Biology, Biodiversity,

Ecology Building, SE-223 62 Lund, Sweden.

E-mail:leif.nilsson@biol.lu.se

Hakon Kampe-Persson, Pulmañi, Glūdas pagasts,

Jelgavas novads, LV-3040 Nākotne, Latvia.

E-mail: kampepersson@hotmail.com

Received 5 September 2017, Accepted 27 May 2018, Editor: Dennis Hasselquist

\section{Introduction}

Like most other goose populations in Europe, the Greylag Goose Anser anser has shown a marked increase in numbers in recent decades (Nilsson et al. 1999, Kampe-Persson 2002, 2010, Fox et al. 2010, Nilsson 2013, Fox \& Madsen 2017). The populations in mainland north-western Europe (the East Atlantic Flyway population) increased from about 200000 in the early 1990s to more than 600000 twenty years later (Fox et al. 2010) and to 960000 in the most recent report (Fox \& Madsen 2017). This very marked increase in the population of Greylag Geese, as well as in other goose species, that started in the 1970s led to many complaints about farmland crop damages (Buij et al. 2017). Therefore, research projects including neck-banding of Greylag Geese and other species were started in many countries to increase the knowledge about the movement patterns and the migrations of different goose species. In the Nordic countries, a Greylag Goose project was initiated in 1984 (Andersson et al. 2001). The project was initially aimed for a five-year period but continued during the following years. In SW Scania, in southernmost Sweden, marking stopped after
2009 (but fieldwork continued until 2012) and in Norway marking still continues (2017).

Traditionally, the Greylag Geese in mainland north-west Europe migrated along the east Atlantic coast via staging areas in The Netherlands to winter quarters in Spain, mainly the Guadalquivir Marismas in the south-west of the country (Nilsson et al. 1999, Andersson et al. 2001). Already during the early part of the study period, changes in the migration patterns and staging habits were recorded (Nilsson et al. 1999, Andersson et al. 2001, Nilsson 2006, Nilsson 2013). This change resulted in fewer geese from southern Sweden migrating to south-western Spain. Instead new traditions were established with wintering areas in northern Spain and further north in The Netherlands. Some Greylag Geese even started to winter in Sweden.

In the present study, we analyse the data from the neck-banding project in SW Scania for the entire study period 1984-2012. A former major analysis (Andersson et al. 2001) also covered neck-banding at other sites in Sweden but these projects were terminated earlier and the re-sightings from them are not analysed in this paper. 


\section{Material and methods}

\section{Marking area}

The marking (i.e., neck-banding and ringing) area for this study was situated in south-western Sweden (SW Scania, Figure 1). The main marking efforts were made at four (later two) lakes in a relatively small area in an undulating open agricultural landscape with small patches of woodland in the western lake area (Figure 1). The marking sites were all eutrophic lakes with rich reed beds Phragmites australis along parts of the shores. Some of the lakes have small islands suitable for breeding geese. Grasslands and at one lake a golf course offered good feeding conditions for the goose families. A description of the area is found in Nilsson \& Persson (1994). The breeding population of Greylag Geese increased from 120 pairs in 1985 to a peak of 1340 pairs in 2004, and thereafter the population decreased and in 2012 there were 820 pairs the area. Various aspects of the breeding ecology and dynamics of this population have been studied (Nilsson \& Persson 1992, 1994, 2001a, 2001b, Nilsson et al. 1997, 2002, Nilsson 1998). During the first years of the study, geese were also neck-banded at two lakes in the eastern lake area of Scania (Figure 1).

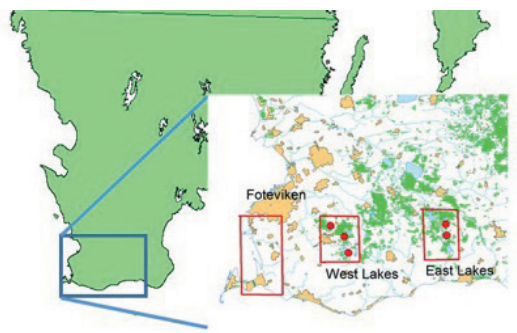

Figure 1. Map of South Sweden with the position of the main study areas inserted. Neck-banding sites are marked with red dots. The main neck-banding and ringing was undertaken in the West Lakes area, where the most intensive studies were conducted during the entire period. Some markings were made in the East Lakes area during the first years of the study. Foteviken at the coast is an important staging area for Greylag Geese from the West Lakes area and was together with the lake area regularly searched for neck-banded geese. Karta över södra Sverige med undersökningsområdena markerade. Märklokaler har markerats med röda prickar. Huvuddelen av märkningarna ägde rum i det västra sjöområdet där mer intensiva undersökningar gjordes under hela perioden. Några märkningar genomfördes $i$ det östra sjöområdet i början av undersökningsperioden. Foteviken vid kusten är ett viktigt område för gässen från det västra sjöområdet och genomsöktes tillsammans med sjöområdet regelbundet efter märkta gäss.
In SW Scania, due to all other studies of the Greylag Geese, all major sites for the species were checked for the occurrence of marked individuals at least on a weekly basis during the breeding season (arrival to early summer). The same applies to the coastal staging sites in the local region (Figure 1) during late summer and early autumn when families from the study area concentrated here.

\section{Catching and marking}

In SW Scania, breeding families were caught on the breeding sites when the goslings were about six weeks old and the parents were unable to fly due to wing moult. The families were rounded up when feeding on grasslands, pastures or a golf course and driven into nets, which were mounted beforehand (Persson 1994a, 2000a, Kampe-Persson 2004). We kept the geese in large jute sacks when they awaited handling.

The geese were marked with blue neck collars of UV-resistant laminated plastic. The collars had three-digit codes engraved with the first character larger and the two following smaller and in right angel to the first one. Letters and numbers most liable to misidentification were omitted. In good light conditions, it was possible to read the codes at a distance of 500-600 m. To make it possible to follow the individuals in the study area also in the case they lost their neck-collars, a proportion of the Greylag Geese were also marked with coloured leg rings with an engraved code. All individuals were also marked with metal rings from the Swedish national ringing scheme. For further information on the Nordic marking scheme, see Andersson et al. (2001). The mean annual retention rate of neckcollars in this study was $93.1 \pm 1.6 \%$ for males and $98.8 \pm 0.5 \%$ for females (Persson 2000b and unpubl.)

\section{Material}

During the years 1984-2008, a total of 2639 Greylag Geese, 685 moulting birds and 1954 goslings, were neck-banded in the study area in SW Scania and included in the present study. Most moulting birds were breeding adults but there were also about 20 non-breeders, most of them from the local population.

When one re-sighting per country and month was counted, in all 15296 re-sightings of the neck-banded Greylag Geese were reported from other areas than the local study area up to and including year 2012 (Table 1). In addition to the re-sightings spec- 
Table 1. Number of neck-banded Greylag Goose Anser anser individuals from SW Scania reported from different countries together with the number of re-sightings reported (one re-sighting per country and month included). Re-sightings from the marking area and the local study area in SW Scania are not included in the table. Re-sightings reported until the end of year 2012 included. Antalet halsmärkta grågäss från SV Skåne rapporterade från olika länder tillsammans med antalet rapporterade observationer (en observation per land och månad inkluderade). Observationer från märkningsområdet och det lokala undersökningsområdet i SV Skåne är inte medtagna i tabellen. Tabellen visar observationer rapporterade till och med 2012.

\begin{tabular}{lrr}
\hline Country & Individuals & Re-sightings \\
\hline Norway & 12 & 29 \\
Sweden & 270 & 675 \\
Denmark & 479 & 1509 \\
Germany & 367 & 997 \\
The Netherlands & 1299 & 7451 \\
Belgium & 112 & 489 \\
UK & 8 & 80 \\
France & 157 & 272 \\
Spain & 758 & 3776 \\
Morocco & 3 & 9 \\
Poland & 1 & 1 \\
Hungary & 1 & 1 \\
Austria & 1 & 1 \\
Tunisia & 5 & 6 \\
\hline Total & & 15296 \\
\hline
\end{tabular}

ified in this table, 100050 re-sightings were obtained locally in the study area in SW Scania in connection with other studies during the same time period (Nilsson \& Persson 1991, 1992, 1994, Nilsson \& Kampe-Persson 2017).

Re-sightings from areas outside the study area in SW Scania were obtained through a large network of voluntary observers that checked the flocks of geese for the occurrence of neck-banded individuals. One of the authors (HKP) carried out several research projects on marked Greylag Geese in Spain during the winters 1985/1986-2001/2002, also visiting staging/wintering areas in The Netherlands, France and Portugal (Persson 1993, 1996a, 1997, Kampe-Persson 2002).
Since 2007 a website (www.geese.org) has been created on which observers can enter their readings of goose rings. On this website a lot of re-sightings, also from the past, were entered by observers through google-maps. The website encourages volunteers to report sightings, because they can check online where the bird they have observed has been ringed and which other re-sightings of the same bird that have been made.

\section{Results}

\section{Distribution of staging and wintering Greylag Geese}

The general migration pattern of the Greylag Geese marked in SW Scania in the early part of the study period has been described in Andersson et al. (2001). In the present study, we therefore concentrate on comparing the migration patterns from the later years with that of the early part of the study period to elucidate changes in migration habits.

The majority of the Greylag Geese seen outside the study area in SW Scania have been reported from The Netherlands and Spain (Figures 2-4), whereas much fewer have been reported from other countries (Table 1). During the first years of the project, up to $50 \%$ of the neck-banded individuals reported in a single year were seen in The Netherlands at least once, whereas the highest annual percentage reported from Spain was somewhat more than $35 \%$. In both cases, the proportion of neck-banded individuals reported have decreased over the years, partly as an effect of changes in the migration pattern as discussed below, but other factors such as the intensity of search is also a factor of importance. It should be kept in mind that the goose populations increased dramatically during this time-period, so it was more difficult to find neck-banded geese with the same fieldwork effort. The Guadalquivir Marismas was intensively searched for marked geese up to 2002 but not thereafter. This can have influenced the number of marked geese reported from this wintering area in later years.

During the summer, most reports of neck-banded Greylag Geese were from the study area with some records from other parts of South Sweden (Figure 4). In the early period, a number of non-breeding Greylag Geese from SW Scania were reported from the moulting area in Oostvaardersplassen in Flevoland in The Netherlands during late May to early July, whereas only single observations were obtained from The Netherlands in these months 


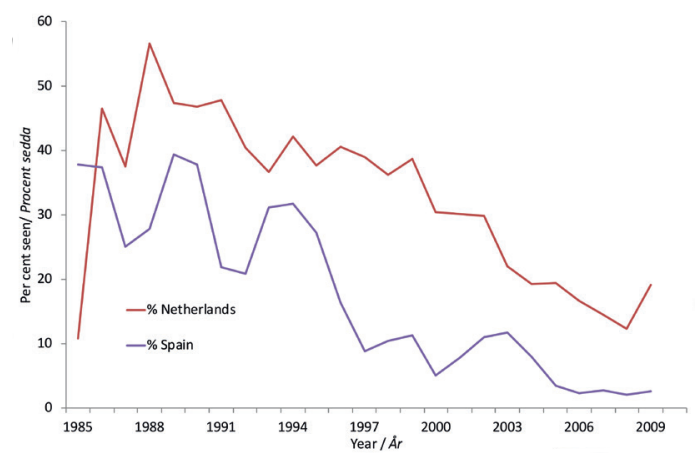

Figure 2. Annual percentages of neck-banded Greylag Geese Anser anser marked in SW Scania reported in a specific year, which were seen in The Netherlands and Spain that year.

Procentandelen märkta grågäss från SW Skåne rapporterade ett givet år, vilka setts $i$ Nederländerna resp. Spanien samma år.
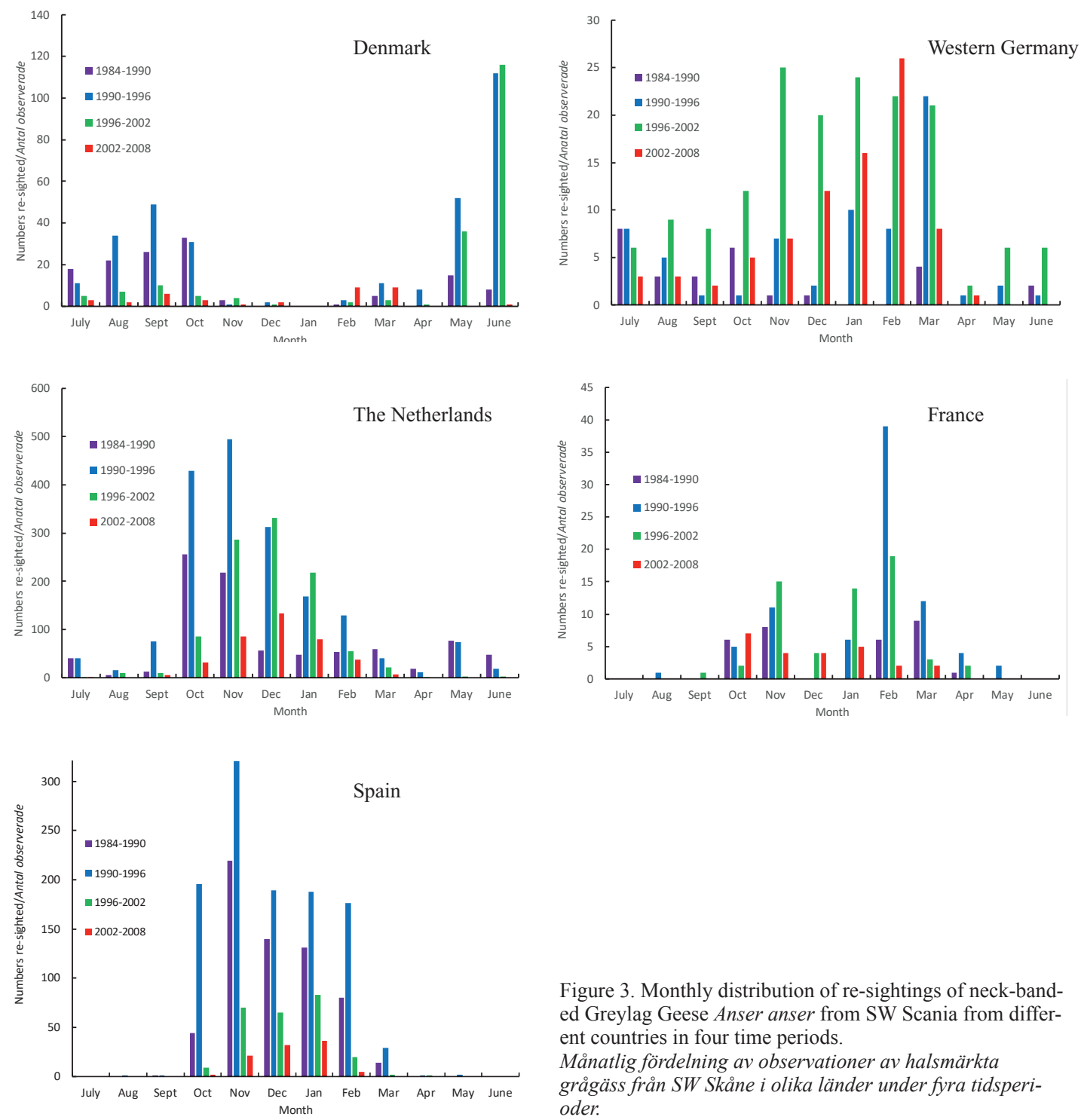

Figure 3. Monthly distribution of re-sightings of neck-banded Greylag Geese Anser anser from SW Scania from different countries in four time periods.

Månatlig fördelning av observationer av halsmärkta grågäss från $S W$ Skåne i olika länder under fyra tidsperioder. 

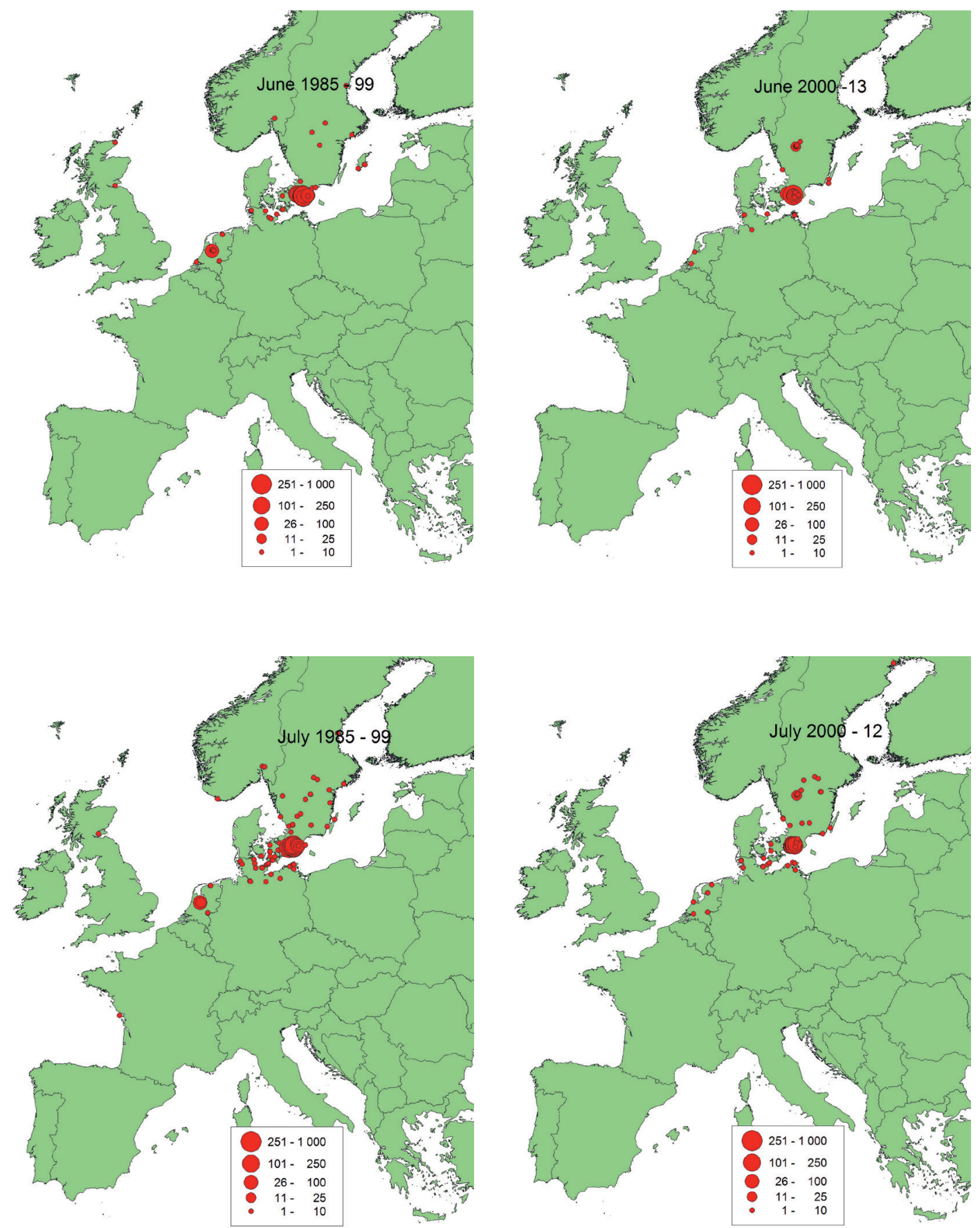

Figure 4. Monthly distribution of re-sightings of neck-banded of Greylag Geese Anser anser from SW Scania during 1985-1999 and 2000-2012, respectively.

Månadsfördelning av observationer av halsmärkta grågäss från SW Skåne under 1985-1999 och 2000-2012. 

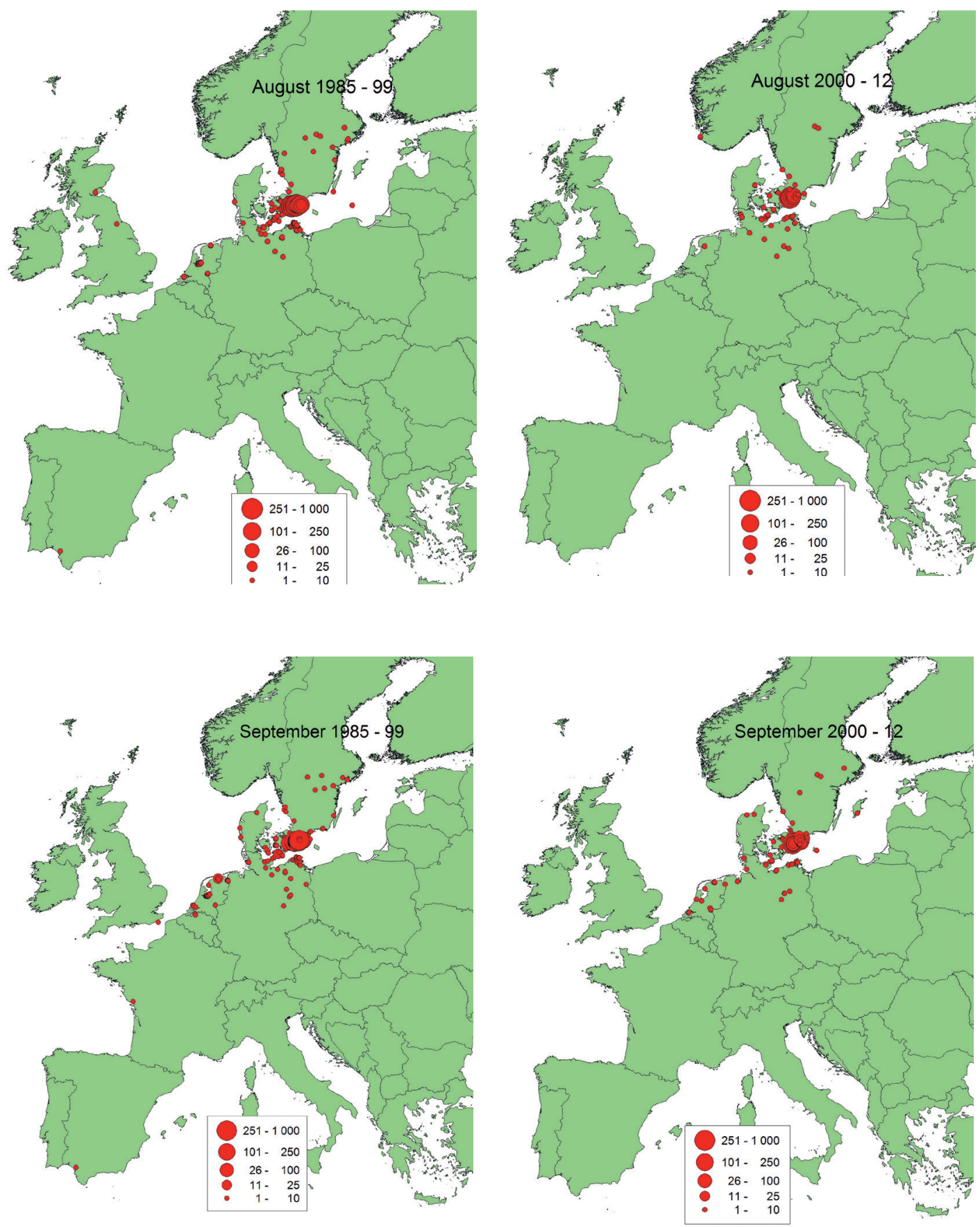

Figure 4. Monthly distribution of re-sightings of neck-banded of Greylag Geese Anser anser from SW Scania during 1985-1999 and 2000-2012, respectively.

Månadsfördelning av observationer av halsmärkta grågäss från SW Skåne under 1985-1999 och 2000-2012. 

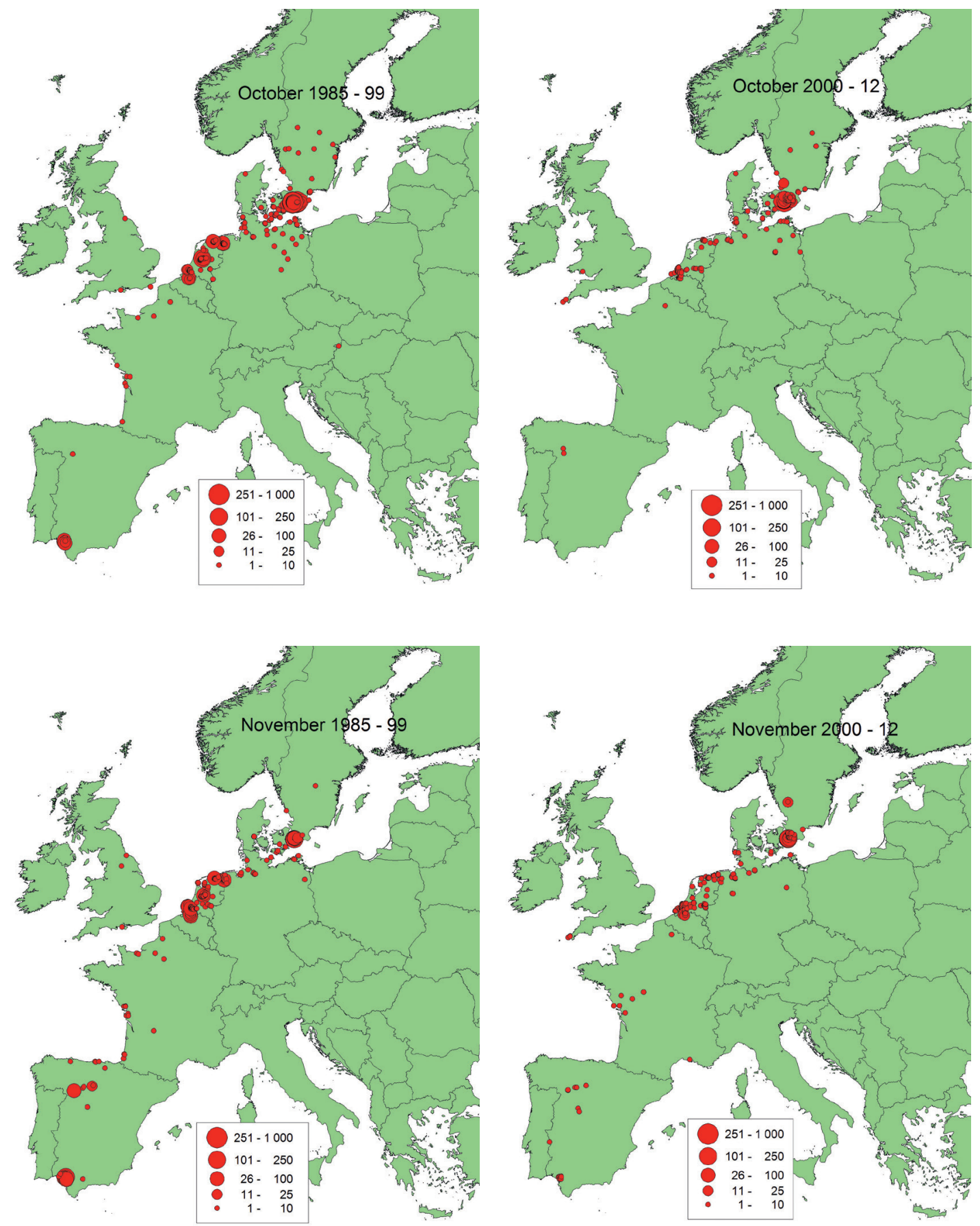

Figure 4. Monthly distribution of re-sightings of neck-banded of Greylag Geese Anser anser from SW Scania during 1985-1999 and 2000-2012, respectively.

Månadsfördelning av observationer av halsmärkta grågäss från SW Skåne under 1985-1999 och 2000-2012. 

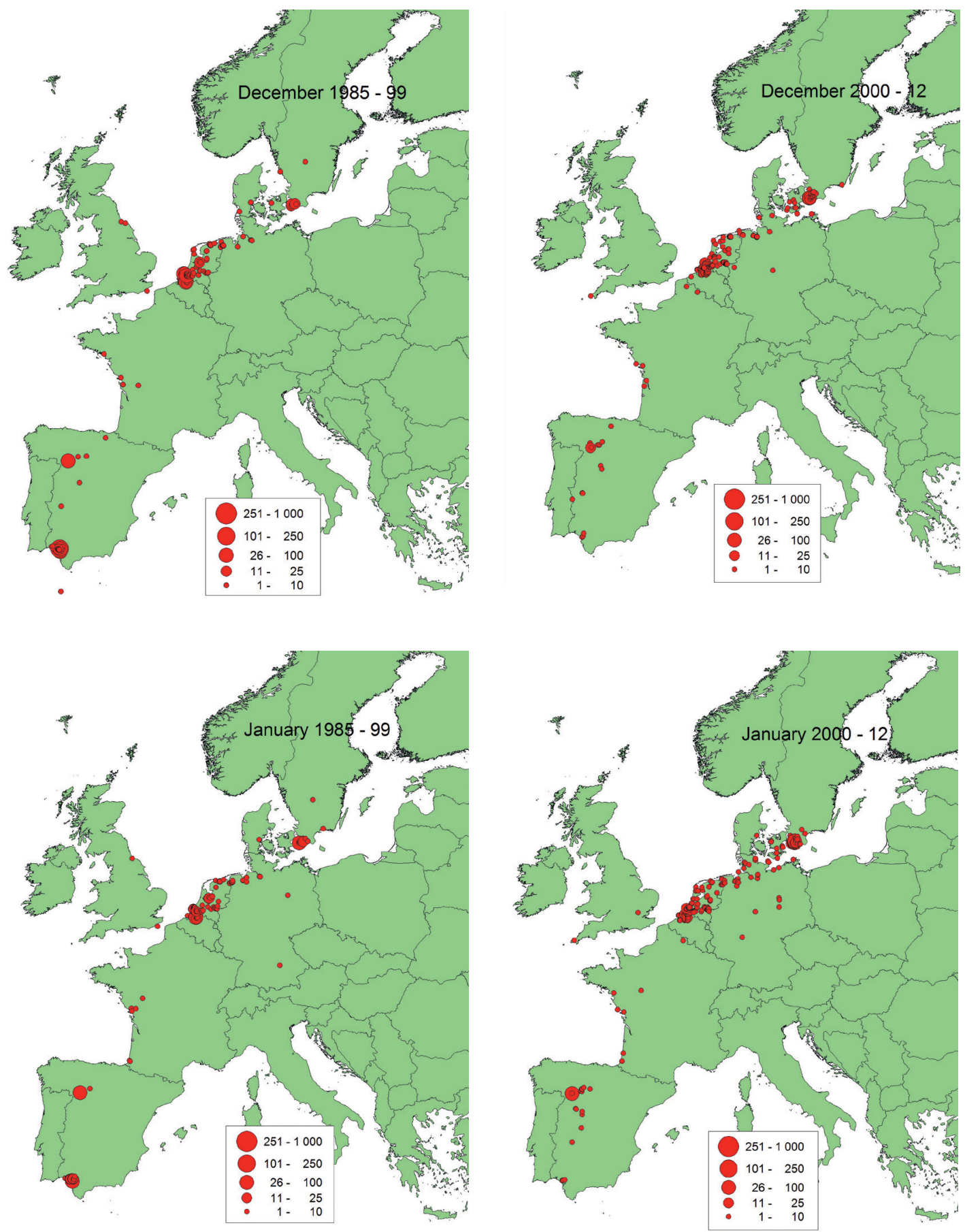

Figure 4. Monthly distribution of re-sightings of neck-banded of Greylag Geese Anser anser from SW Scania during 1985-1999 and 2000-2012, respectively.

Månadsfördelning av observationer av halsmärkta grågäss från SW Skåne under 1985-1999 och 2000-2012. 

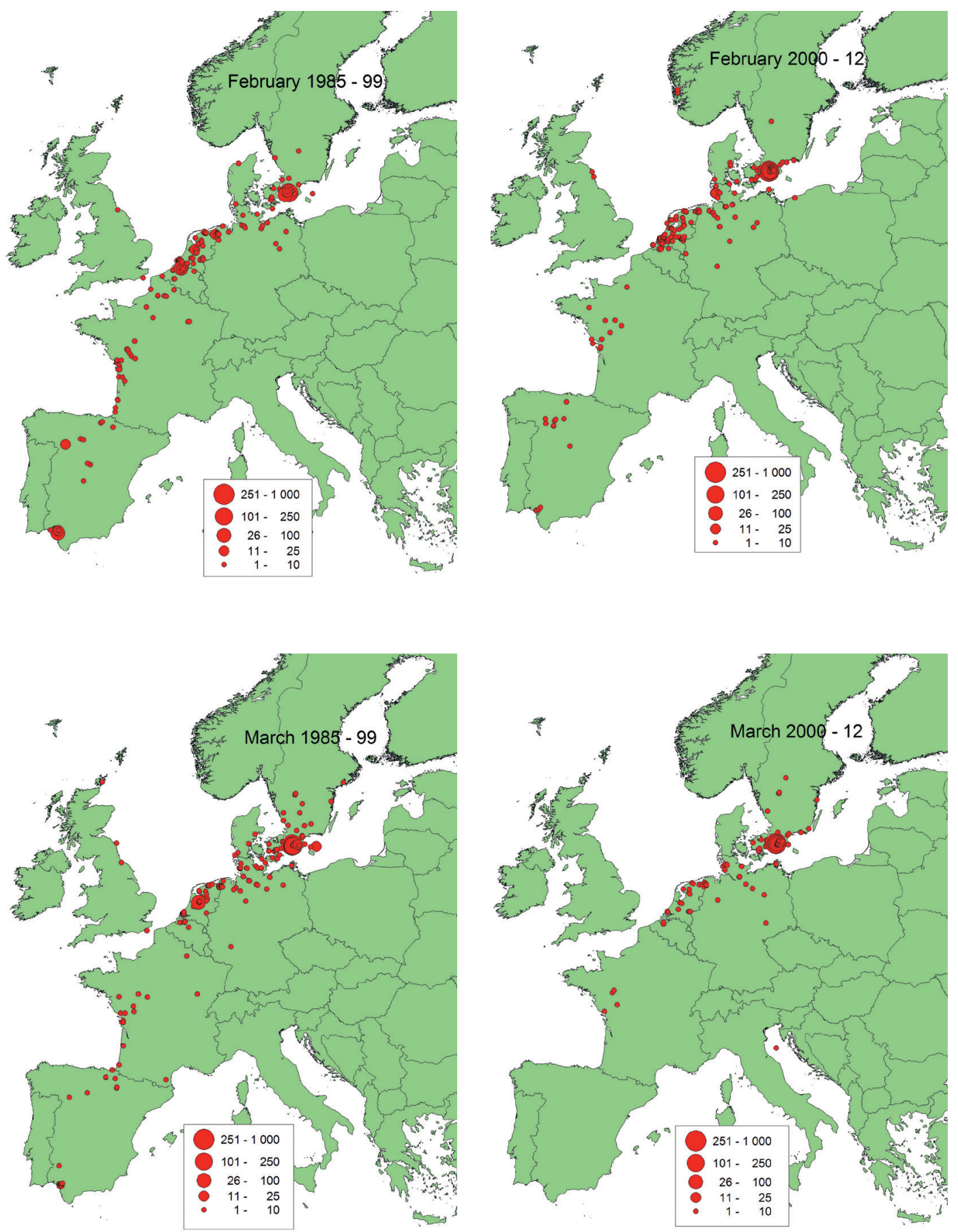

Figure 4. Monthly distribution of re-sightings of neck-banded of Greylag Geese Anser anser from SW Scania during 1985-1999 and 2000-2012, respectively.

Månadsfördelning av observationer av halsmärkta grågäss från SW Skåne under 1985-1999 och 2000-2012. 

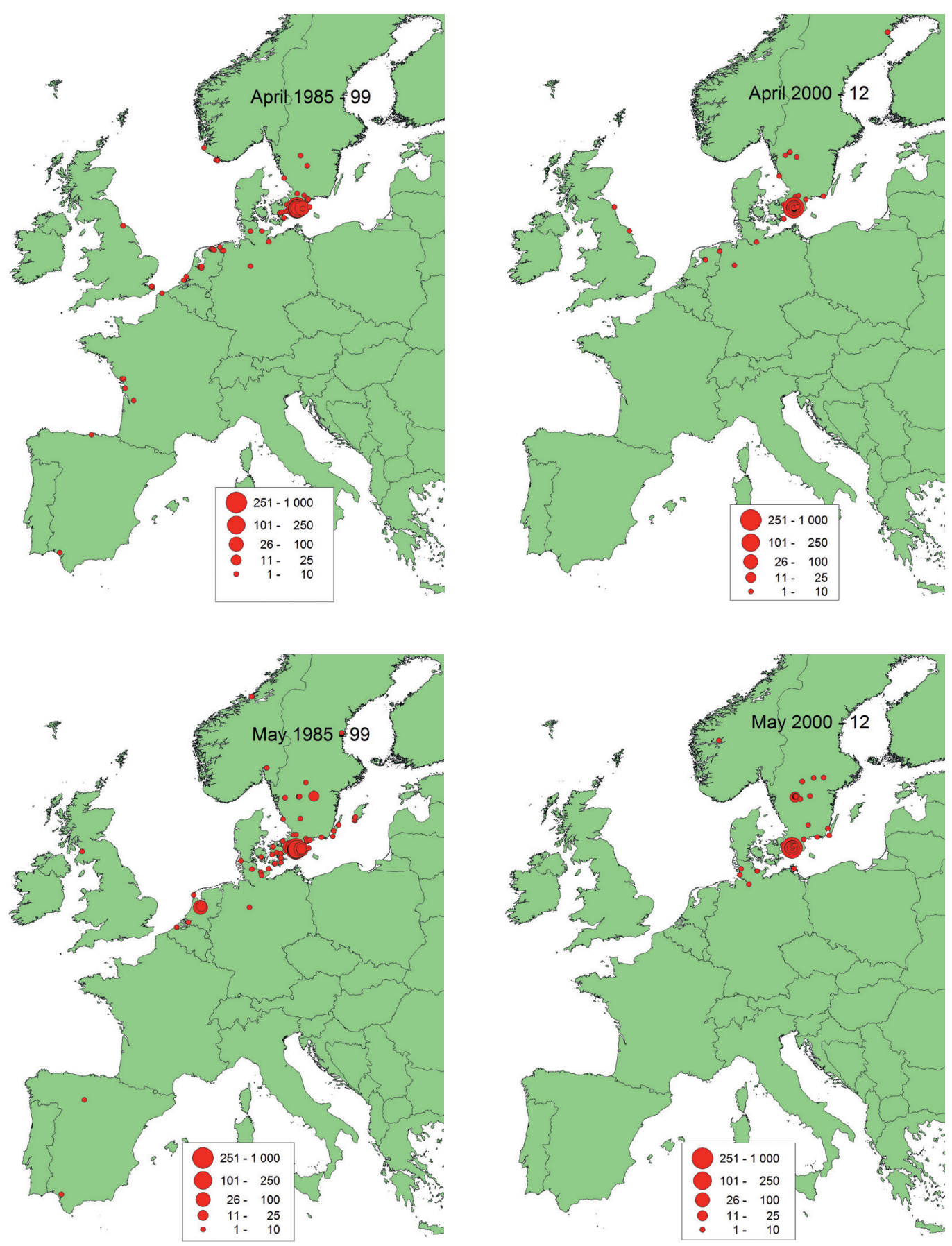

Figure 4. Monthly distribution of re-sightings of neck-banded of Greylag Geese Anser anser from SW Scania during 1985-1999 and 2000-2012, respectively.

Månadsfördelning av observationer av halsmärkta grågäss från SW Skåne under 1985-1999 och 2000-2012. 

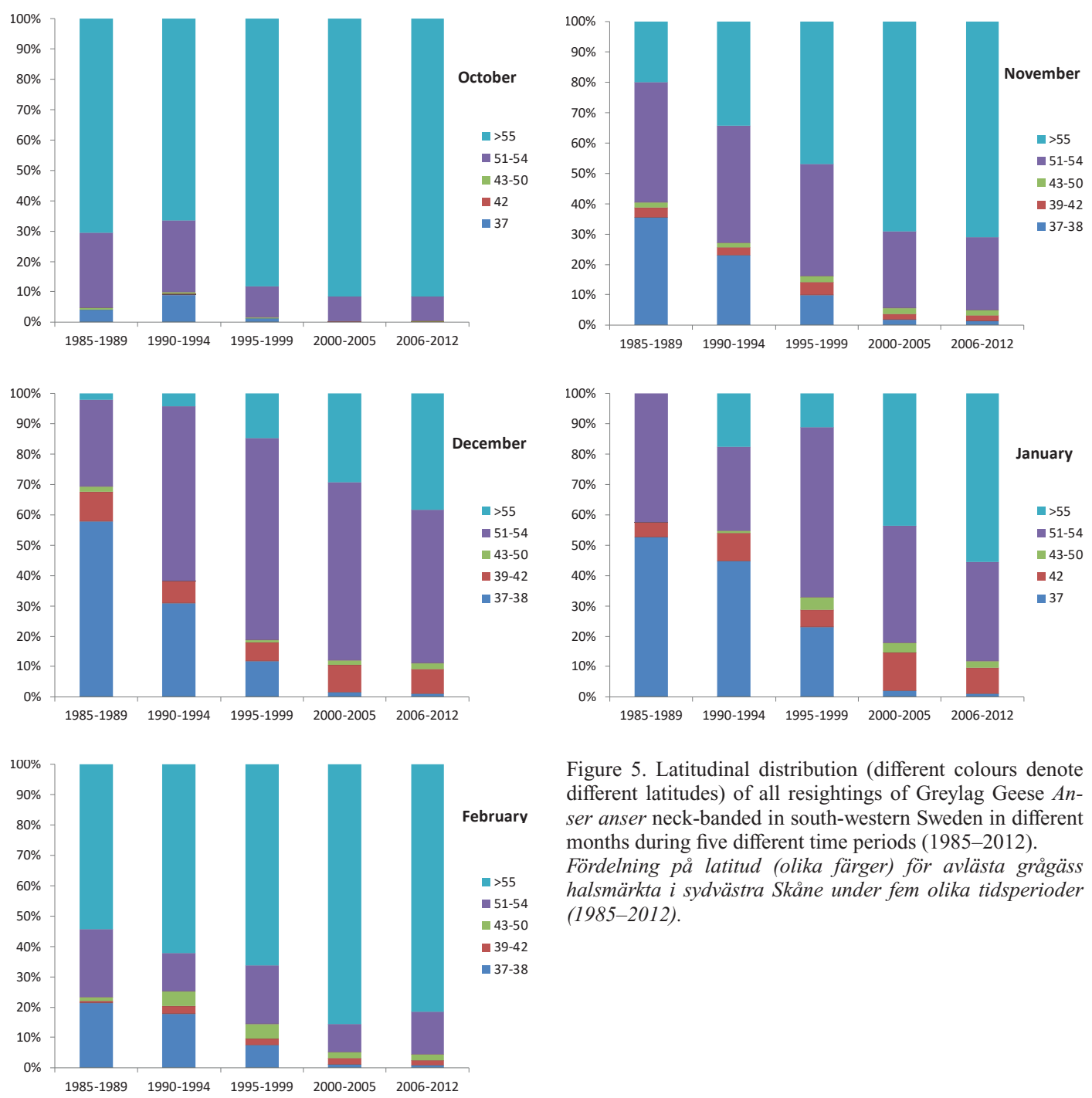

Figure 5. Latitudinal distribution (different colours denote different latitudes) of all resightings of Greylag Geese Anser anser neck-banded in south-western Sweden in different months during five different time periods (1985-2012).

Fördelning på latitud (olika färger) för avlästa grågäss halsmärkta i sydvästra Skåne under fem olika tidsperioder (1985-2012).

during later years (Figure 3). Numbers moulting at Oostvaardersplassen decreased already during the 1990s, when a new moulting tradition for south Swedish Greylags was established on the island of Saltholm between south Sweden and Denmark (Fox et al. 1995, Nilsson et al. 2001) and hardly any Greylag Geese from SW Scania went to Oostwaardersplassen anymore. Thus, during a period in the 1990s (due to intensive fieldwork on Saltholm in connection with the impact assessment for the bridge between Sweden and Denmark) more observations of marked Greylag Geese from SW Scania were reported from Denmark in June than from any other month (Figure 3). Unfortunately, the intensive studies on Saltholm stopped after year 2000 and there is therefore no information about geese from Scania there in later years. However, Greylag Geese still go there to moult as numbers counted on the moulting site was 46500 in 2011 (Michael Flink pers. comm.). In later years, also a number of Greylag Geese marked in SW Scania were reported as moulting in Lake Hornborgasjön (Nilsson \& Hermansson in prep.).

In late summer, after the moult, and in early au- 
tumn, the majority of the Greylag Geese remained in SW Scania close to the marking areas, but there was a shift in the local distribution with a concentration to coastal areas (Nilsson \& Persson 1992, Nilsson 2013, Nilsson \& Kampe-Persson 2017). Smaller numbers stayed in Denmark, The Netherlands and northern Germany during this time of the year (Figures 3-5). Re-sightings from The Netherlands in late summer were restricted to the early part of the study period, when Greylag Geese from Scania still moulted at Oostwaardersplassen. Most German re-sightings during August and September were from Mecklenburg-Vorpommern.

October and November was the main migration period for the Greylag Geese from SW Scania during the early years and a large proportion of the neck-banded birds was reported from The Netherlands. In these months, marked differences were found between the different time periods. During the early part of the study an appreciable proportion of the geese were already reaching south-western Spain in October and the staging and wintering areas in The Netherlands and Spain dominated over the areas in the north, for example Sweden, in November. In the later years, the majority of the Greylag Geese remained in Sweden during this time of the year. Small numbers were found in The Netherlands in October but hardly any reached Spain in that month. The picture was similar for November in the late period with much fewer south Swedish Greylag Geese reaching Spain compared to in the earlier years.

December and January are typical winter months and Greylag Geese were found all along the flyway from SW Scania to southern Spain. When comparing the two time-periods for these months it has been a clear shift in the distribution, especially during January. Within Spain, two areas were important during the first time-period, the Guadalquivir Marismas in the south-west and Villafáfila in the north, whereas very few geese were found in the former area in January during 2000-2012. Moreover, Greylag Geese from SW Scania were reported from a number of new sites in Spain during the latter period. It is also clear that more Greylag Geese were on migration northwards in January during the latter time-period compared to the first period. Re-sightings from South Sweden were more common in later years. Over the study period, there was a northward change of the mean latitude for January re-sightings of marked Greylag Geese from Scania (Figure 6).

In February, Greylag Geese were found along the entire flyway and spring migration northwards was

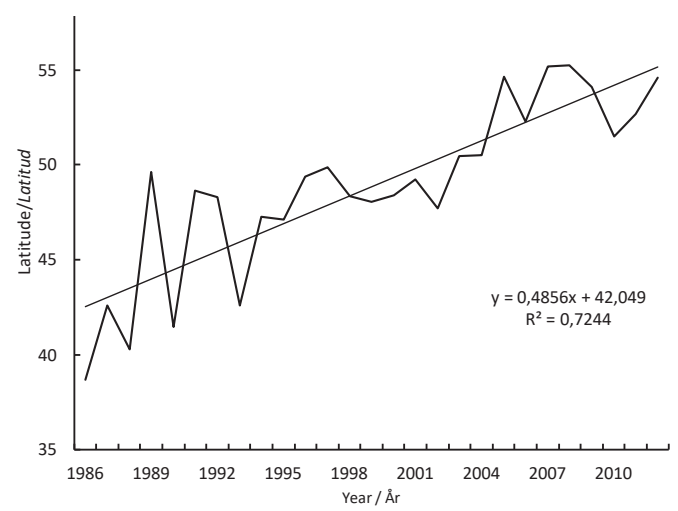

Figure 6. Mean latitude for January observations of neck banded Greylag Geese Anser anser from SW Scania in 1986-2017.

Medel-latitud för januariobservationer av halsmärkta grågäss från SW Skåne 1986-2017.

apparent even during the early period. The northern distribution bias was more apparent during the second period (2000-2012). Similar patterns were seen in March, when very few Greylag Geese were still found south of The Netherlands in 2000-2017.

In April, most reports were from the breeding areas with some individuals lingering around in the north, fewer were found south of Sweden in the second period than during the first period (19851994). In May, the moult migration to Oostvaardersplassen in The Netherlands was apparent in the first time-period, whereas no geese were reported from this area in May during the second period.

Outside the main flyway from south-west Sweden, only few reports have been obtained of marked Greylag Geese from other areas. As is seen from the maps small numbers have been seen regularly in Britain and there are a few observations further to the east in Europe. A few individuals from southwest Sweden established a breeding population in Britain, probably somewhere in Scotland and migrating to wintering areas in England (cf. Insley 1997).

The maps (Figure 4) clearly show that marked changes in the migration pattern and wintering areas of the Greylag Geese from south-west Scania have occurred over the years of the study. These changes became still clearer when the distribution of the re-sightings was analysed according to latitudinal distribution (Figure 5). The differences are most prominent for December and January, when almost all re-sightings were from The Netherlands and Spain during the first period (1985-1999), with no re-sightings reported from the marking area. 
In the second period, an increasing proportion of the birds were found wintering in Sweden. In the same time period, the numbers wintering in Spain decreased markedly. Over the period 1986-2012, the mean latitude for January re-sightings changed about ten degrees northwards, the trend being highly significant (Figure 6). This change towards more northerly wintering areas continued during the entire study period.

When the study started only few Greylag Geese were found in SW Scania during the January counts. In the same way there were no winter observations of neck-banded Greylag Geese from Scania during the first years of the study. Beginning in 1991, small numbers of marked Greylag Geese remained in SW Scania in most winters, staying mainly close to the coast at Foteviken. Suddenly, in 2005, this number increased and $25 \%$ of all marked Greylag Geese seen that year were seen in Scania during the winter (Figure $5 \mathrm{a}-\mathrm{c}$ ), with more that $30 \%$ of the neck-banded geese staying in the winter of 2009.

Over the years, $13 \%$ of the re-sighted Greylag Geese changed winter quarter between two consecutive winters (Table 2). The highest frequency of change was seen for the two Spanish winter areas ( $14 \%$ and $15 \%$, respectively), whereas only $8 \%$ of those wintering in SW Netherlands changed winter area between two consecutive seasons. Clearly, the number of changes shown in Table 2 are biased to the low side as all geese were not reported in the winter in all years (not being seen). In addition to the 29 changes recorded between two consecutive years a further 27 changes were noted for geese that were not recorded in consecutive winters. The majority of the changes were from a southern winter area to a more northern winter area (Table 3) but there were six geese changing from the Netherlands to Spain. There is, however, a possibility that some of these birds were late migrants staging in the Netherlands not being seen later the same year in Spain.

\section{Phenology of migration}

The monthly distribution of reported re-sightings of neck-banded Greylag Geese from different countries gives a good picture of the phenology of the migration for the species through the main staging and wintering areas (Figures 3,4). For Denmark, the picture was markedly dominated by the number of Greylag Geese reported from the moulting site at Saltholm in May-June during a number of years in the 1990s. Very few observations were reported from Denmark during November-February, but generally, the number of reported re-sightings from Denmark was quite small. Apparently, most Greylag Geese just passed over Denmark on their migration south.

The picture for Western Germany is quite different from the Danish one. During the first years, few Swedish Greylag Geese were reported from Germany outside the migration periods, but in the latter

\begin{tabular}{|c|c|c|c|c|}
\hline \multirow[t]{2}{*}{ Area } & \multicolumn{3}{|c|}{ Number of individuals } & \multirow{2}{*}{$\begin{array}{l}\text { Per cent } \\
\text { changing }\end{array}$} \\
\hline & No Change & Change & Total & \\
\hline Guadalquivir delta & 45 & 8 & 53 & 15 \\
\hline Villafafila & 23 & 0 & 23 & 0 \\
\hline N Spain excl. Villafafila & 12 & 2 & 14 & 14 \\
\hline France & 2 & 3 & 5 & + \\
\hline SW Netherlands & 96 & 8 & 104 & 8 \\
\hline Flevoland & 8 & 1 & 9 & + \\
\hline N Netherlands & 5 & 3 & 8 & + \\
\hline NW Germany & 0 & 4 & 4 & + \\
\hline SW Scania & 5 & 0 & 5 & + \\
\hline Total & 196 & 29 & 225 & 13 \\
\hline
\end{tabular}

Table 2. Number of neck-banded Greylag Geese Anser anser from SW Scania changing winter quarters between years for individuals where the winter quarter was established in two consecutive years.

Antal halsmärkta grågäss från SV Skåne som bytt vinterkvarter mellan år, för gäss där vinterkvarteret fastställts två på varandra följande år. 
Table 3. Shifts of winter quarters by neck-banded Greylag Geese Anser anser from SW Scania separated between those seen on different winter areas in two consecutive years (Table 2) and those seen on the second winter quarter later (=year of change unknown).

Byte av vinterkvarter för halsmärkta grågäss från SV Skåne, separat för dem som setts två på varandra följande år (Tabell

2) och dem som setts $i$ det nya vinterområdet senare (år för bytet okänt).

\begin{tabular}{|c|c|c|c|c|}
\hline Winter area 1 & Winter-area 2 & Second Winter & Later Winter & Total \\
\hline Gualdalquivir & SW Netherlands & 6 & 7 & 13 \\
\hline Gualdalquivir & Villafafila & 0 & 5 & 5 \\
\hline Gualdalquivir & France & 1 & 0 & 1 \\
\hline Gualdalquivir & SW Scania & 1 & 1 & 2 \\
\hline N Spain & SW Netherlands & 2 & 2 & 4 \\
\hline N Spain & NW Germany & 0 & 1 & 1 \\
\hline France & Villafafila & 1 & 0 & 1 \\
\hline France & SW Netherlands & 2 & 0 & 2 \\
\hline SW Netherlands & SW Scania & 5 & 9 & 14 \\
\hline Netherlands & Spain & 5 & 1 & 6 \\
\hline N Netherlands & SW Netherlands & 1 & 0 & 1 \\
\hline N Netherlands & NW Germany & 1 & 0 & 1 \\
\hline N Netherlands & SW Scania & 10 & 1 & 1 \\
\hline NW Germany & SW Netherlands & 3 & 0 & 3 \\
\hline NW Germany & SW Scania & 1 & 0 & 1 \\
\hline Total & & 29 & 27 & 56 \\
\hline
\end{tabular}

part of the study period, a number of observations of marked Swedish Greylag Geese were reported from the winter months and early spring. There are some reports of moulting Swedish Greylag Geese from the German west coast in May-June.

As mentioned before, the largest number of resightings of Scanian Greylag Geese were reported from The Netherlands. During the early years, the highest numbers were reported from the autumn period, with much smaller number of re-sightings reported from the other months. Over the years, there was a change in the pattern with the highest counts reported from October 1984-1990, in November in 1990-1996 and in December for the last two periods (1996-2008).

France was mainly a passage country for the Greylag Geese from SW Scania (Figure 2). Very few observations were reported before October. Peak number of observations were noted in November and February (during the first period March). Few geese from Scania stayed in France over the winter. For further details on the occurrence of Greylag Geese in France, see Nilsson et al. (2013). The majority of the Greylag Geese from SW Scania migrating to Spain apparently made a direct flight from the Netherlands to Spain (Persson 1993, 1994b). We assume that it was the extremely high hunting pressure in France (Persson 1999) made the geese reluctant to stage there

Spain is the southernmost wintering area for the Greylag Geese from SW Scania even if a few individuals have been recorded in Morocco. During the first two periods (1984-1996), many Greylag Geese were seen in Spain but especially in the last period (2002-2008; Figure 3), the number of observations was small. The data from Spain is a little biased as one of the authors (HKP) made intensive field work in the area up to 2002. The data from Spain clearly show a change in the wintering phenology. In the first part of the study Greylag Geese from SW Scania arrived in October, but later the arrival was in November.

In The Netherlands, there is a great interest in reading and reporting neck-bands and other marks on birds and this therefore offers a very good opportunity to follow changes in the timing of the 


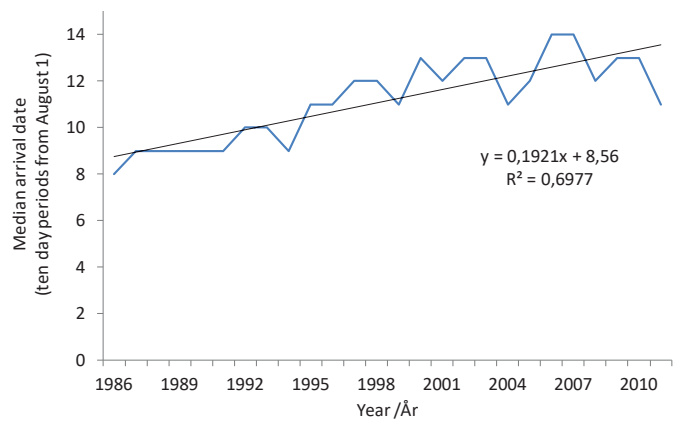

Figure 7. Median arrival dates in autumn in The Netherlands in different years during ten-day periods from August 1st for Greylag Geese Anser anser marked in SW Scania.

Median för första observation under hösten i Nederländerna $i$ tiodagarsperioder från 1 augusti för grågäss märkta i SW Skåne.

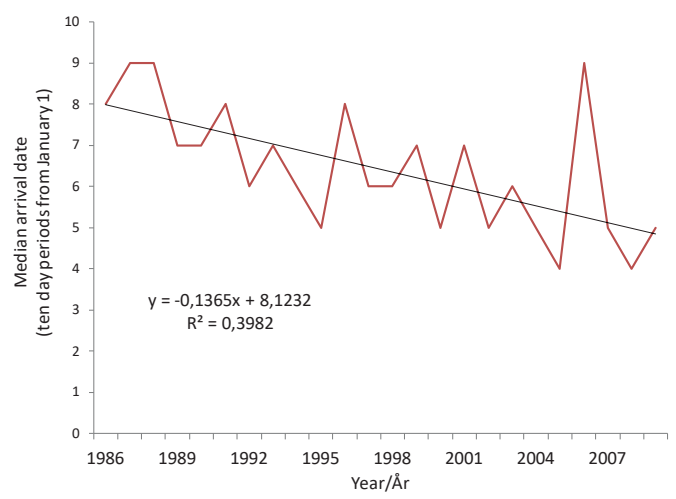

Figure 8. Median arrival dates in spring in SW Scania, South Sweden in different years during ten-day periods from January 1st for Greylag Geese Anser anser marked in the area in earlier years.

Median för första observation under våren i sydvästra Skåne under olika år i tiodagarsperioder från 1 januari för grågäss märkta $i$ området under tidigare år.

Greylag Goose migration as a very large proportion of the geese stay here for longer or shorter periods during the autumn migration. Thus, calculating annual median dates for the first observation of neck-banded Greylag Geese in The Netherlands give a good indication of changes in the time-table of autumn migration, which is much better than comparing last-sightings of the birds in the staging areas in Scania. During autumn, the Greylag Geese in Scania are dispersed over a large area for feeding during the day and it is difficult to establish with certainty when they leave the region on migration. Between 1987 and 2011 there has been a significant trend towards a later arrival of the marked birds in The Netherlands (Figure 7), the median arrival date for the last few years being about one month later (early November) compared to the start of the study (early October).

The timing of spring arrival of the Greylag Geese from SW Scania has also changed significantly during the study period (Figure 8), and the median arrival date back to Scania during the last few years is now ca. one month earlier than at the beginning of the study. For Greylag Geese known from winter re-sightings to winter in Spain, about 20\% were back in the breeding areas in Scania in February during 1986-1990 compared to more than $40 \%$ in 2001-2005 (Figure 9).

\section{Discussion}

The reason why only few birds used Denmark as a staging area in the autumn, just passing over the country on the migration to the staging areas in The Netherlands, may be that the distance is short and easy to complete in a few hours. In the same way, few of the marked Scanian Greylag Geese used France as a staging area on the migration from The Netherlands to the wintering areas in Spain (Nilsson et al. 2013). The distance from The Netherlands to south-western Spain was usually covered by a non-stop flight (Persson 1993, 1994b).

The changes in the migration and wintering habits of the Greylag Geese from south-west Scania shown in the analysis of neck-banded individuals in this contribution are also reflected in the results from the ordinary goose counts (Nilsson 2013).

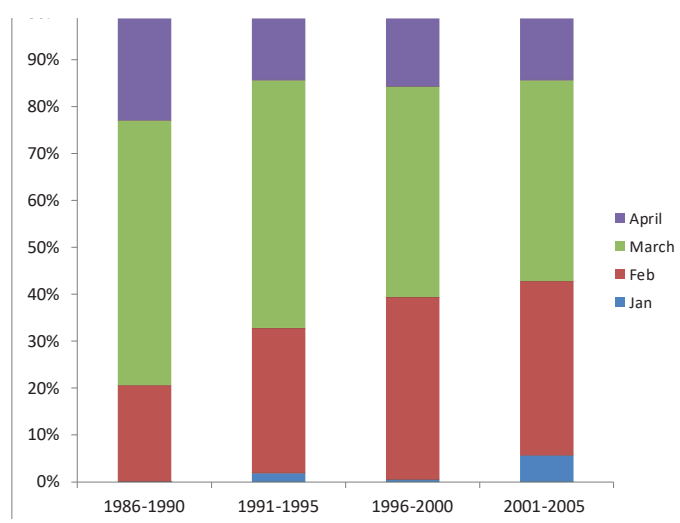

Figure 9. Monthly distribution of first spring observations of neck-banded individuals during different time periods in the breeding area in SW Scania, South Sweden, for Greylag Geese Anser anser wintering in Spain.

Månadsfördelning av första vårobservationer av halsmärkta individer under olika tidsperioder i häckningsområdet i $S W$ Skåne för grågäss som övervintrat i Spanien. 
Before year 2000, hardly any Greylag Geese stayed in Scania over the winter. However, after 2000 the numbers wintering in southern Sweden increased markedly with a peak count in 2008 of about 50000 Greylag Geese. This is about $25 \%$ of the total count of the species in the special survey in September the preceding autumn (Nilsson 2013, Nilsson \& Haas 2016). The departure of the geese of the neck-banded population leaving the country was later during the study period. Thus, both October and November counts increased over the years and a larger proportion of the Greylag Geese counted in September stayed in October and November. This increase in the number of geese staying longer in the autumn was noted before the start of the wintering tradition of Greylag Geese in Sweden (Nilsson 2013). On the European scale, these changes in winter distribution of Greylag Geese have been discussed by Ramo et al. (2015).

This type of northern range shift has been reported for other goose species both from Sweden and from other countries. In Spain, the Tundra Bean Goose Anser fabalis rossicus declined from perhaps 200000 birds in the 1930s to none in the mid1990s (Persson \& Urdiales 1995). Whether this was due to deterioration of conditions in Spain, or improvements at wintering areas closer to breeding areas (or a combination of both) is not known. In North America, there are several examples of how improved conditions along the migration routes have shifted the winter distribution northwards in both the Canada Goose Branta canadensis and the Snow Goose Anser caerulescens (for references, see Elmberg et al. 2014).

In Sweden, the Taiga Bean Goose Anser fabalis fabalis breeding in the north has also changed migration and wintering habits (Nilsson 1984, 2011, 2013, Nilsson \& Persson 1984) staging further north in Sweden during autumn and to a large extent wintering in south Sweden and/or Denmark and not migrating to The Netherlands and Western Germany any more. The timing of migration has also changed and the Taiga Bean Geese arrive earlier to the spring staging areas in northern Sweden nowadays compared to in the late seventies (Nilsson \& Persson 1984, Nilsson unpublished). In one of the most important staging and wintering areas for this taxon, NE Scania, the geese nowadays arrive much later in autumn and leave much earlier in spring than some decades ago (Kampe-Persson 2014).

The changes in winter distribution and migration pattern in the Greylag Goose have been quite fast occurring over a short time period. This is, how- ever, not unique for the Greylag Goose but has been found in several other goose species, showing the large flexibility in the migration behaviour of geese. In Sweden, the number of autumn staging Barnacle Geese Branta leucopsis has increased markedly in the last few years. Actually, there has been a change in the entire migration strategy for the Russian population of the species related to changes in the availability of staging sites in the Baltic (Eichhorn et al. 2009). Other fast changes in the migration pattern seen in Sweden is the occurrence of larger numbers of Tundra Bean Geese in recent years (Nilsson 2013, Kampe-Persson 2014) and a higher number of staging Pink-footed Geese Anser brachyrhynchus in south-central Sweden in autumn and spring (Nilsson 2013).

Several duck species have also changed the winter distribution northwards. In Sweden, Nilsson \& Haas (2016) found such changes in the winter distribution of several species as an effect of milder winters. Lehikoinen et al. (2013) and Pavon-Jordan et al. (2015) found similar changes when comparing duck census data from a number of countries.

Besides climate change, changes in the availability of suitable crops for feeding can be a factor contributing to the changes in winter distribution and migration habits for the geese. For the Greylag Geese, the later migration from Sweden coincided with changes in the feeding habits of the geese in Scania (Nilsson \& Persson 1998, Nilsson \& Kampe-Persson 2013), as the geese starting to utilize fields with leftover sugar beet in the autumn. The agricultural landscape of South Sweden nowadays offers the geese a succession of good feeding opportunities over the entire season. This change in the availability of food in combination with milder winters and less snow cover creates better possibilities for the geese to stay in South Sweden over the winter. Changes in agriculture and suitable crops for feeding was probably also an important factor behind the change in autumn staging habits for the Taiga Bean Geese in Sweden.

Changes in the migration habits of the Greylag Geese from SW Scania over the years were not only found in the regular migrations to and from the wintering areas. Young, non-breeding geese migrate to traditional moulting sites in early summer (Salomonsen 1968). In the early years of the study, the Greylag Geese from Scania migrated to Flevoland in The Netherlands for moulting (Andersson et al. 2001) but as the population of Greylag Geese in Western Europe increased and the moulting site in Flevoland reached its carrying capacity (Zijlstra et al. 1991), Greylag Geese from South Sweden 
started to change their moult migration. Eventually, a large proportion of Greylag Geese from Scania were found moulting on the neighbouring island of Saltholm in the Øresund between Sweden and Denmark (Fox et al. 1995, Nilsson et al. 2001). When the moulting tradition for Scanian Greylag Geese started on Saltholm is not known because the systematic work on the island only started in 1994, when a number of marked geese were found here.

\section{Acknowledgements}

The Nordic Greylag Goose project started in 1984 with grants from the Nordic Collegium for Wildlife Research. Later work on the Greylag Goose in Sweden was supported by grants from the Swedish Environmental Protection Agency, Carl Trygger's Foundation for Scientific Research, the Swedish Association and the Øresund Bridge Consortium (as a part of an impact assessment study).

We also express our sincere thanks to all those thousands of bird-watchers which over the years have checked the goose flocks all over Europe, reporting hundreds of thousands of re-sightings to us and recently to the data-base www.geese.org. Without this massive support from voluntary observers the study could never have been done.

\section{References}

Andersson, Å., Follestad, A., Nilsson, L. \& Persson, H. 2001. Migration patterns of Nordic Greylag Geese Anser anser. Ornis Svecica 11: 19-58.

Buij, R., Melman, T.C.P., Loonen, M.J.J.E. \& Fox, A.D. 2017. Balancing ecosystem function, services and disservices from expanding goose populations. Ambio 46 Suppl. 2: S301-S318.

Calderón, J., Mañez, M. \& García, L. 1991. A note on wintering Greylag Geese Anser anser of the Guadalquivir Marismas. Ardea 79: 269-270.

Eichhorn, G., Drent, R.H., Stahl, J., Leito, A. \& Alerstam, T. 2009. Skipping the Baltic: the emergence of a dichotomy of alternative spring migration strategies in Russian barnacle geese. Journal of Animal Ecology 78: 63-72.

Elmberg,J. Hessel, R., Fox, A.D. \& Dalby, L. 2014. Interpreting seasoal range shifts in migratory birds: a critical assessment of "short-stopping" and a suggested terminology. Journal of Onrithology 155:571-579.

Fox, T., Ebbinge, B.S., Mitchell, C., Heinicke, T., Aarvak, T., Colhoun, K., Clausen, P., Dereliev, S., Faragó, S., Koffijberg, K., Kruckenberg, H., Loonen, M.J.J.E., Madsen, J., Mooij, J., Musil, P., Nilsson, L. Pihl, S. \& van der Jeugd, H. 2010. Current estimates of goose population sizes in Western Europe, a gap analysis and assessment of trends. Ornis Svecica 20: 115-127.

Fox, A.D., Kahlert, J., Ettrup, H., Nilsson, L. \& Hounisen, J.P. 1995. Moulting Greylag Geese Anser anser on the Da- nish island of Saltholm; numbers, phenology, status and origins. Wildfowl 46: 16-30.

Fox, A.D. \& Madsen, J. 2017. Threatened to super-abundance: The unexpected international implications of successful goose conservation. Ambio 46(Suppl. 2): S179-S187.

Kampe-Persson, H. 2002. Anser anser Greylag Goose. BWP Update 4: 181-216.

Kampe-Persson, H. 2004. Halsringmärkning av häckande grågäss i Skåne 1984-2004. Ringinform 27: 34-36.

Kampe-Persson, H. 2010. Naturalised geese in Europe. Ornis Svecica 20: 155-173.

Kampe-Persson, H. 2014. Staging and wintering Taiga Bean Geese Anser fabalis fabalis in north-east Scania, south Sweden. Ornis Svecica 24: 56-78.

Lehikoinen, A., Jaatinen, K., Vähätalo, A.V., Clausen. P., Crowe, O., Deceuninck, B., Hearn, R., Holt, C.A., Hornman, M., Kewller, V., Langedoen, T., Tomankova, I., Wahl, J. \& Fox, A.D. 2013. Rapid climate driven shifts in wintering distributions of three common waterbird species. Global Change Biology 19: 2071-2081.

Nilsson, L. 1984. Migrations of Fennoscandian Bean Geese Anser fabalis. Swedish Wildlife Research 13: 83-106.

Nilsson, L. 1998. The Greylag Goose Anser anser as a model species for the study of waterfowl breeding ecology. Acta Zoologica Lituanica, Ornithologia 8: 20-28.

Nilsson, L. 2006. Changes in migration patterns and wintering areas of south Swedish Greylag Geese Anser anser. Pp 514-516 in Waterbirds around the World (Boere, G.C., Galbraith, C.A. \& Stroud, D.A., eds.). The Stationary Office. Edinburgh, UK.

Nilsson, L. 2011. The migrations of Finnish Bean Geese Anser fabalis in 1978-2011. Ornis Svecica 21: 157-166.

Nilsson, L. 2013. Censuses of staging and wintering goose populations in Sweden 1977/78-2011/12. Ornis Svecica 23: $3-45$.

Nilsson, L., Follestad, M.A., Koffijberg, K., Kuijken, E., Madsen, J., Mooij, J., Mouronval, J.B., Persson, H., Schricke, V. \& Voslamber, B. 1999b. Greylag Goose Anser anser: Northwest Europe. Pp 182-201 in Goose populations of the Western Palearctic. A review of status and distribution (Madsen, J., Cracknell, G. \& Fox, A.D., eds). Wetlands International Publ. No. 48, Wetlands International, Wageningen, The Netherlands. National Environmental Research Institute, Rønde, Denmark.

Nilsson, L., Green, M. \& Persson, H. 2002. Field choice in spring and breeding performance of Greylag Geese Anser anser in southern Sweden. Wildfowl 53: 7-25.

Nilsson, L. \& Haas, F. 2016. Distribution and numbers of wintering waterbirds in Sweden in 2015 and changes during the last fifty years. Ornis Svecica 26: 3-54.

Nilsson, L. Kahlert, J. \& Persson, H. 2001. Moult and moult migration of Greylag Geese Anser anser from a population in Scania, south Sweden. Bird Study 48: 129-138.

Nilsson, L. \& Kampe-Persson, H. 2013. Field choice of autumn staging and wintering geese in southwestern Sweden 1977/78-2011/12. Ornis Svecica 23: 46-60.

Nilsson, L. \& Kampe-Persson, H. 2017. Local movements of Greylag Geese Anser anser in South Sweden during the non-breeding season. Ornis Svecica 27: 13-22.

Nilsson, L. \& Persson, H. 1984. Non-breeding distribution, numbers and ecology of Bean Goose, Anser fabalis, in Sweden. Swedish Wildlife Research 13: 107-170.

Nilsson, L. \& Persson, H. 1991. Selection and exploitation of 
feeding areas by staging and wintering geese in southernmost Sweden. Ornis Svecica 1: 81-92.

Nilsson, L. \& Persson, H. 1992. Feeding areas and local movement patterns of post-breeding Greylag Geese Anser anser in South Sweden. Ornis Svecica 2: 77-90.

Nilsson, L. \& Persson, H. 1994. Factors affecting the breeding performance of a marked Greylag Goose Anser anser population in south Sweden. Wildfowl 45: 33-48.

Nilsson, L. \& Persson, H. 1996. The influence of the choice of winter quarters on the survival and breeding performance of grelag geese (Anser anser). Gibier Faune Sauvage, Game Wildlife 13: 557-571.

Nilsson, L. \& Persson, H. 1998. Field choice of staging Greylag Geese Anser anser in relation to changes in agriculture in South Sweden. Ornis Svecica 8: 27-39.

Nilsson, L. \& Persson, H. 2001a. Change of mate in a Greylag Goose Anser anser population: effects of timing on reproductive success. Wildfowl 52: 31-40.

Nilsson, L. \& Persson, H. 2001b. Natal and breeding dispersal in the Baltic Greylag Goose Anser anser. Wildfowl 52: 21-30

Nilsson, L., Persson, H. \& Voslamber, B. 1997. Factors affecting survival of young Greylag Geese and their recruitment into the breeding population. Wildfowl 48: 72-87.

Pavon-Jordan, D., Fox, A.D., Clausen, P., Dagys, M., Deceuninck, B., Devos, K., Hearn, R.D., Holt, C.A., Hornman, M., Keller, V., Langedoen, T., Lawickii, L., Lorentsen, S.H., Luigujoe, L., Meissner, W., Musil, P., Nilsson, L., Paquet, J.-Y., Stipniece, A., Stroud, D.A., Wahl, J., Zenaqtello, M. \& Lehikoinen, A. 2015. Climate-driven changes in winter abundance of a migratory waterbird in relation to EU protected areas. Diversity and Distributions (2015): $1-12$.

Persson, H. 1993. Arrival patterns of Greylag Geese Anser anser in the Guadalquivir Marismas. Wildfowl 44: 19-23.

Persson, H. 1994a. Neck-banding of Greylag Geese Anser anser in Scania, 1984-1993. Anser 33: 101-106. (in Swedish with English summary).

Persson, H. 1994b. Autumn migration in the Greylag Goose Anser anser; non-stop flight from the Netherlands to Coto de Doñana? Limosa 67: 79-80. (in Dutch with English summary).

Persson, H. 1996a. Survival rates and breeding success in a marked Greylag Goose Anser anser population, wintering in the Guadalquivir Marismas. Revista Florestal 9: 189-199.

Persson, H. 1997. Gestión de las poblaciones de gansos en el Paleártico Occidental. Pp. 1-17 in Las Salinas de Villafáfila: "Humedal estratégico europeo para aves". Colegio Oficial de Veterinarios de Zamora - A.D.R.I. "Palomares", Zamora.

Persson, H. 1999. La chasse á l'Oie cendrée Anser anser en France... ou de l'exploitation excessive d'une resource naturelle. Alauda 67: 223-230.

Persson, H. 2000a. Neck-collaring of Greylag Geese Anser anser in Scania, 1984-2000. Anser 39: 167-172. (in Swedish with English summary).

Persson, H. 2000b. Neck collar retention in a Greylag Goose Anser anser population. Ornis Svecica 10: 155-160.

Persson, H. \& Urdiales, C. 1995. The disappearance of the Tundra Bean Goose Anser fabalis rossicus from the Iberian Peninsula. IWRB Goose Research Group Bulletin 6: 17-19.
Ramo, C., Amat, J.A., Nilsson, L., Schricke, V., RodriguezAlonso, M., Gomez-Crespo, E., Jubete, F., Navedo, J.S., Masero, J.A., Palacios, J., Boos, M. \& Green, A.J. 2015. Latitudinal-Related Variation in Wintering Population Trends of Greylag Geese (Anser anser) along the Atlantic Flyway: A Response to Climate Change? Plos One 10(10): e0140181.

Salomonsen, F. 1968. The moult migration. Wildfowl 19: 5-24.

\section{Sammanfattning}

I likhet med de flesta andra gåsbestånd i Europa har grågåsen visat en markant beståndsökning under senare decennier (Nilsson 2013) och den nordvästeuropeiska populationen beräknas nu till ca 960 000 individ (Fox \& Madsen 2017). Som en följd av de markanta ökningarna av gåsbestånden kom många klagomål rörande gåsskador (Buij et al. 2017). Detta ledde i sin tur till att flera forskningsprogram rörande gäss startade runt om i Europa. I de nordiska länderna startade ett grågåsprojekt med bl.a. halsmärkning av grågäss 1984 (Andersson et al. 2001). Projektet var ursprungligen planerat för en femårsperiod, men i SW Skåne fortsatte märkningarna till 2009 (och kontroller efter märkta gäss till och med 2012) och i Norge till och med 2017.

Traditionellt flyttade grågässen från nordvästeuropas fastland längs Atlantkusten söderut via rastplatser i främst Nederländerna till vinterområden i Spanien, huvudsakligen Guadalquivirs delta i den sydvästra delen av landet (Nilsson et al. 1999, Andersson et al. 2001). Under de år vi studerade grågässens flyttningsvanor noterades betydande förändringar med färre övervintrande grågäss från sydligaste Sverige i södra Spanien och en ökad övervintring längre norrut främst i Nederländerna (Nilsson 2006).

I denna uppsats analyserar vi hela det insamlande materialet från halsmärkningarna i SW Skåne för 1985-2012 för att belysa förändringar i grågässens flyttningsvanor och val av övervintringslokaler. Vi uppdaterar därmed den tidigare analysen som publicerades av Andersson et al. (2001).

\section{Material och metoder}

Den sydsvenska delen av undersökningarna koncentrerades till två sjöområden i södra Skåne (Figur 1). Huvuddelen av märkningarna skedde i det västra sjöområdet främst koncentrerade till två sjöar; Klosterviken och Yddingen. Under de första åren märktes också en del grågäss i det östra sjöområdet. Förutom flyttningsundersökningarna genomfördes ett flertal andra studier av olika aspekter på grågåsens ekologi i det västra sjöområdet (Nilsson 
\& Persson 1992, 1994, 2001a, 2001b, Nilsson et al. 1997, 2002, Nilsson 1998).

Fångst ägde rum på häckningsområdena när ungarna var ca. sex veckor gamla och då föräldrarna fortfarande var flygodugliga på grund av ruggning. Gässen drevs in i nätfållor för att kunna märkas. Gässen märktes med halsringar av UV-beständig plast, vilka hade en ingraverad kod med tre tecken. Alla gäss märktes dessutom med en RC-ring. Vissa av dem fick också en plastring med graverad kod på det andra benet.

Totalt märktes 685 vuxna gäss och 1954 ungar i området under projektet. Fram till och med 2012 erhölls 15296 rapporter om avlästa gäss utanför märkområdet. Därtill kommer 100050 avläsningar från undersökningsområdet i södra Skåne.

\section{Resultat}

De tidiga resultaten från det nordiska grågåsprojektet har tidigare presenterats av Andersson et al. (2001). I denna uppsats koncentrerar vi oss därför på att jämföra flyttningsmönstret hos grågässen i början och i slutet av undersökningsperioden för att belysa de stora förändringar som skett under de år undersökningarna pågått.

Merparten av de märkta grågäss som setts utanför undersökningsområdet har rapporterats från Nederländerna och Spanien (Figur 2 - 4) med betydligt färre observationer av märkta gäss från andra länder (Tabell 1). Under de första åren av projektet rapporterades upp till $50 \%$ av de individer som sågs ett givet år från Nederländerna, medan andelen för Spanien var något lägre, ca 35\% (Figur 2). Genom åren har denna andel minskat dels beroende på ökande gåsbestånd och dels på grund av gässens ändrade flyttningsvanor.

Den månatliga utbredningen av rastande och övervintrande grågäss under den tidiga och sena delen av undersökningsperioden illustreras i en serie kartor (Figur 4), medan gässens tidsmässiga uppträdande under olika perioder i viktiga länder illustreras i en serie diagram (Figur 3). Under sommaren kommer flertalet avläsningar från Sverige, men under den tidiga delen av studien rapporterades flera avläsningar också från Nederländerna under sommaren, då många gäss flög till Flevoland för att rugga. I takt med att gässen blev vanligare minskade antalet ruggare som flög till Flevoland och en ny ruggningsplats etablerades på Saltholm i Öresund. Under senare delen av 1990-talet gjordes däremot ett större antal avläsningar under ruggningsperioden på Saltholm i Öresund, men dessa undersökningar upphörde år 2000.
Oktober och november var de huvudsakliga flyttningsmånaderna för de skånska grågässen och många rapporter om märkta gäss erhölls från speciellt Nederländerna, men under de tidiga åren nådde en del märkta gäss i Spanien redan i oktober. Genom åren skedde en senareläggning av flyttningen söderut och de senaste åren nådde få gäss Spanien under hösten. Gässen har också stannat längre norrut under den senare delen av undersökningsperioden (Figur 5).

December och januari är typiska vintermånader för grågässen och observationer har erhållits längs hela flyttningsstråket från Sydsverige ner till södra Spanien. Under vintern har en mycket markant förskjutning norrut skett i grågässens vinterutbredning (Figur 5,6). Medel-latituden för januariobservationerna av märkta grågäss visade en stadigt ökande trend och försköts under undersökningsperioden ca 10 grader norrut (Figur 6). För ett betydande antal individer har vinterkvarteret kunnat fastställas under två på varandra följande år (Tabell 2). Totalt bytte minst $13 \%$ av gässen vinterkvarter mellan två år, nästan i samtliga fall innebar detta att de övervintrade längre norrut (Tabell 3).

Genom åren har grågässen också kommit att stanna allt längre tid i södra Sverige. Det är alltid svårt att säkert fastställa när de märkta gässen lämnar ett område, men det är däremot lättare att fastställa när de första observationerna görs. I Nederländerna är ett mycket stort antal ornitologer intresserade av att läsa av färgringar och som nämnts har vi en hög frekvens av avlästa halsringar därifrån. Under de år undersökningarna pågått har medianen för första observationen av halsmärkta gäss från Skåne i Nederländerna inträffat ungefär en månad senare (Figur 7). På motsvarande sätt anländer gässen allt tidigare till häckningsområdena i Skåne (Figur 8) och median ankomsten för de märkta var ungefär en månad tidigare $\mathrm{i}$ slutet av studieperioden. Även bland de grågäss som flyttade ända till vinterområden i södra Spanien var flera individer tillbaka i häckningsområdena i februari. Under åren 19861990 var denna andel 20\%, medan motsvarande andel för åren 2001-2005 var 40\% (Figur 9).

\section{Diskussion}

Grågässen från södra Skåne flyttar söderut längs Europas västkust, ett stråk som utnyttjas också av gäss från andra delar av landet (Andersson et al. 2011, Nilsson in prep. Nilsson \& Hermansson in prep.). Endast få gäss från området rapporterades från andra dela av Europa, till exempel de Brittiska öarna, dit några individer från den skånska populationen uppenbarligen rekryterats till den lokala häckande 
populationen. Analysen av de märkta gässen visar också klart på de betydande förändringar som skett i gässens flyttningsvanor och val av övervintringsområden, vilka förskjutits norrut under de nästan trettio år studien pågått.

Förändringarna i flyttnings- och övervintringsvanor framträder också tydligt i resultaten från de nationella och internationella gåsinventeringarna (Nilsson 2013, Ramo et al. 2015). När gåsinventeringarna startade i Sverige sågs knappt några grågäss i Sverige i januari, medan upp till 50000 räknats under senare år, vilket motsvarar ca $25 \%$ av beståndet föregående höst.

Liknande förändringar i rast och övervintringsvanor har rapporterats från flera andra gåsarter både $\mathrm{i}$ Sverige och från andra länder. Sädgåsen har visat betydande förändringar i sina rastnings- och övervintringsvanor. Sålunda övervintrade stora antal tundrasädgäss under 1930-talet i Spanien, medan de helt saknas där sedan 1990-talet (Persson \& Urdiales 1995). För taigasädgåsen har vi sett liknande förändringar i Sverige, där de numera knappast finns i Skåne tidigt om hösten (Nilsson 1984, 2011, 2013, Nilsson \& Persson 1984). Snabba och stora förändringar i uppträdandet har också noterats i Sverige för den vitkindade gåsen (Eichhorn et al. 2009) samt för tundrasädgåsen och spetsbergsgåsen (Nilsson 2013).

Många olika faktorer kan ha orsakat dessa betydande förändringar $\mathrm{i}$ gässens flyttningsvanor och vinterutbredning. Förändringar i klimatet är en faktor man lätt kommer att tänka på, men därutöver har stora förändringar skett $\mathrm{i}$ jordbruket genom åren samtidigt som de mildare och snöfattiga vintrarna gör att gässen lättare kommer åt födan. Man måste också beakta att gässen ökat markant i antal (Fox \& Madsen 2017), vilket kan ha lett till ökad konkurrens. 